John Carroll University

Carroll Collected

\title{
Eastern Red-backed Salamanders Regulate Top- Down Effects in a Temperate Forest-Floor Community
}

\author{
Carl Anthony \\ John Carroll University, canthony@jcu.edu \\ Cari-Ann M. Hickerson \\ John Carroll University, chickerson@jcu.edu \\ B. Michael Walton \\ Cleveland State University
}

Follow this and additional works at: https://collected.jcu.edu/fac_bib_2017

Part of the Biology Commons

\section{Recommended Citation}

Anthony, Carl; Hickerson, Cari-Ann M.; and Walton, B. Michael, "Eastern Red-backed Salamanders Regulate Top-Down Effects in a Temperate Forest-Floor Community" (2017). 2017 Faculty Bibliography. 33.

https://collected.jcu.edu/fac_bib_2017/33 


\title{
Eastern Red-backed Salamanders Regulate Top-Down Effects in a Temperate Forest-Floor Community
}

\author{
Cari-Ann M. Hickerson ${ }^{1,3}$, Carl D. Anthony ${ }^{1}$, and B. Michael Walton ${ }^{2}$ \\ ${ }^{1}$ Department of Biology, John Carroll University, University Heights, OH 44118, USA \\ ${ }^{2}$ Department of Biological, Geological and Environmental Sciences, Cleveland State University, Cleveland, OH 44115, USA
}

\begin{abstract}
AвSTRACT: Understanding the role of species interactions as regulatory mechanisms for ecosystem processes presents a challenge to ecologists working in systems with high species diversity and habitat complexity. Recent studies suggest that interactions among intraguild predators, such as terrestrial salamanders and large arthropods, might be important for the regulation of detritivores, fungivores, and perhaps detritus within terrestrial webs. A key prediction is that interactions among predators weaken trophic cascades. Our research examined this prediction by removing predators for $4 \mathrm{yr}$ from unfenced field plots to investigate the effects on litter arthropods, the microbial community, and rates of leaf litter decomposition. We manipulated predator abundance in three treatments (salamander removal, centipede removal, and multiple predator removal) compared to a control in which no predators were removed. Despite difficulties in suppressing centipede numbers, we observed increases in salamanders, millipedes, isopods, slugs, numbers of ant colonies, and gamasid mites in the centipede removal plots. Additionally, several phospholipid fatty acid markers for bacteria were suppressed in plots where salamanders were most abundant. Finally, we detected treatment effects on the rate of litter disappearance from leaf bags in our field plots: those with the most salamanders had the lowest levels of litter decomposition. Overall, we found some evidence for top-down effects of predators in a temperate forest-floor web. Our study is one of few that have employed an unfenced field design and the only study examining the effects of salamanders on forest soil microbes. The results contribute to a growing body of evidence indicating that territorial predators, such as terrestrial salamanders, can be strong regulators of species composition at lower trophic levels in a system that is commonly thought to be regulated primarily through bottom-up effects of organic matter supply.
\end{abstract}

Key words: Arthropods; Leaf litter decay; Phospholipid fatty acid analysis; Plethodon cinereus; Soil microbes; Trophic cascade

TROPHic CASCADEs occur when predation changes the abundance, biomass, or productivity of populations or communities across two or more trophic links (Pace et al. 1999). Although often considered more common in aquatic ecosystems, many studies have indicated that top-down trophic cascades occur in terrestrial systems (e.g., Pace et al. 1999; Schmitz et al. 2000; Halaj and Wise 2001; Beard et al. 2003; Ripple et al. 2016). Most efforts to understand trophic cascades have focused on aboveground food webs (Dunham 2008). For instance, strong top-down effects of amphibian predators on herbivorous invertebrates and the amount of plant herbivory have been documented (Beard et al. 2002, 2003). Much less is known about the relative strength of topdown versus bottom-up forces within belowground systems, however, even though most global primary production eventually enters detrital food webs (Swift et al. 1979; O’Neill and Reichle 1980; Scheu and Setälä 2002; Wardle 2002). Theory suggests that high species diversity, omnivory, intraguild predation, habitat complexity, nonconsumptive interactions among predators, long chain length, and high web connectivity should attenuate top-down trophic cascades (Scheu and Setälä 2002; Wardle 2002). Despite having many, if not all, of the above mentioned characteristics, studies on temperate forest-floor webs have documented effects of vertebrate predators on various trophic levels including litter invertebrate composition and, in some cases, litter decay and nutrient cycling rates.

A number of studies have focused on the effects of terrestrial plethodontid salamanders on intraguild predators, macrodetritivores, microbivores, and litter decay (Table 1). These salamanders are thought to have great potential to affect carbon retention and nutrient cycling in temperate

\footnotetext{
${ }^{3}$ Correspondence: e-mail, chickerson@jcu.edu
}

forests owing to their large numbers (Semlitsch et al. 2014) and biomass (Milanovich and Peterman 2016). Specifically, Eastern Red-backed Salamanders (Plethodon cinereus) can achieve remarkably high densities within temperate forests of eastern North America (Burton and Likens 1975; Jung et al. 2000), where they play an important role in regulating invertebrates and may mediate rates of leaf litter decomposition (e.g., Wyman 1998). Several studies have shown that Eastern Red-backed Salamanders can have strong positive effects on the density of major microbi-detritivore taxa, especially Collembola, a response that has been associated with salamander-mediated reductions of competitors or predators of Collembola (Wyman 1998; Walton and Steckler 2005; Walton et al. 2006). In contrast, other studies have found strong negative effects of salamanders on some trophic levels in detrital webs. For example, Hickerson et al. (2012) reported negative effects of Eastern Red-backed Salamanders on some intraguild predators such as spiders and centipedes but with positive effects on carabid beetles in unfenced field plots. Salamanders can produce significant reductions in mesofaunal detritivores (e.g., Collembola). For example, Walton (2005) observed reductions in excess of $30 \%$ for some taxa, but this effect varies seasonally. In open field plots salamander effects on litter invertebrate densities varied in magnitude and direction across taxa and also through time (Walton 2013). It has also been hypothesized that salamander predation in mesocosms increases numbers of mesofauna by reducing macrodetritivore competitors, or by subsidizing microbial growth with accumulating salamander feces, or both (Walton and Steckler 2005). Finally, some studies have found little to no effect of Eastern Red-backed Salamanders on invertebrates or litter decay (e.g., Homyack et al. 2010; Hocking and Babbitt 2014). 
TABLE 1.-Summary of studies examining the effects of woodland salamanders on forest-floor communities. Negative and positive symbols indicate salamander effects as determined by increases (positive effects) or decreases (negative effects) reported in the listed literature. "nm" = unmeasured variables.

\begin{tabular}{|c|c|c|c|c|c|}
\hline Authors & Guild members & Macrodetritivores & Microbivore & Microbes & Leaf litter \\
\hline Wyman $1998^{\mathrm{a}}$ & $\mathrm{nm}$ & - & $\mathrm{nm}$ & $\mathrm{nm}$ & + \\
\hline Rooney et al. $2000^{b}$ & $\mathrm{~nm}$ & $\mathrm{~nm}$ & + & $\mathrm{nm}$ & $\mathrm{nm}$ \\
\hline Walton $2005^{\mathrm{c}}$ & $\mathrm{nm}$ & No effect & - & $\mathrm{nm}$ & $\mathrm{nm}$ \\
\hline Walton and Steckler $2005^{\mathrm{a}}$ & $\mathrm{nm}$ & - & + & $\mathrm{nm}$ & No effect \\
\hline Walton et al. $2006^{\mathrm{a}}$ & $\mathrm{nm}$ & - & + & $\mathrm{nm}$ & $\mathrm{nm}$ \\
\hline Homyack et al $2010^{\mathrm{b}}$ & $\mathrm{nm}$ & No effect & No effect & $\mathrm{nm}$ & No effect \\
\hline Hickerson et al. $2012^{\mathrm{c}}$ & $+/-$ & $\mathrm{nm}$ & $\mathrm{nm}$ & $\mathrm{nm}$ & No effect \\
\hline Walton $2013^{\mathrm{c}}$ & $\mathrm{nm}$ & $+1-$ & $+1-$ & $\mathrm{nm}$ & $\mathrm{nm}$ \\
\hline Hocking and Babbitt $2014^{\mathrm{b}, \mathrm{c}}$ & No effect & $\mathrm{nm}$ & $\mathrm{nm}$ & $\mathrm{nm}$ & No effect \\
\hline Best and Welsh $2014^{\mathrm{b}}$ & $\mathrm{nm}$ & $+1-$ & $+1-$ & $\mathrm{nm}$ & + \\
\hline Current study ${ }^{c}$ & $\mathrm{~nm}$ & $+/-$ & No effect & - & + \\
\hline
\end{tabular}

In complex systems, it is clearly difficult to discern patterns that reveal how predators affect, and are affected by, lower trophic levels in forest-floor webs. It is possible that differences in experimental methods, including experiment duration, the taxa considered and the scale of the experiments (mesocosm vs. field enclosures vs. open field plots; see Table 1) are responsible for some of the inconsistencies in the literature that make it difficult to compare results among studies and to determine which mechanisms are the most important drivers of community composition. It has recently been suggested, however, that the discrepancies among study results examining the effects of predators in temperate forest-floor systems might reflect biologically relevant dynamics caused by complex variation in environmental conditions (Best and Welsh 2014) and seasonal litter/soil invertebrate composition (Walton 2013). Specifically, in years where increased rainfall results in increased invertebrate abundance, the effects of salamander predation on invertebrates can be swamped out (Best and Welsh 2014). Differences in territorial investment between spring and fall, coupled with differences in leaf litter thickness, have been shown to change the magnitude of top-down effects of Eastern Red-backed Salamanders on forest-floor food webs. For example, in late summer and autumn (prior to leaf fall), litter mass is low and the litter matrix is relatively simple. During this period, the magnitude of top-down effects is hypothesized to be stronger than in the spring when leaf litter mass and complexity are high (Walton 2013).

Another difficulty in understanding the effects of predation in temperate forest-floor webs is that few studies have addressed predator effects on microbes, the trophic level linking microbivore (e.g., Collembola) densities and rates of litter decomposition (but see Mikola and Setälä 1998; Johnson et al. 2005; Wardle et al. 2011). In addition to Eastern Red-backed Salamanders, mesofaunal microbivores (mites and Collembola) are known to be among the mostabundant organisms in temperate forest-floor systems (Swift et al. 1979) and are therefore probably important regulators of microbes. Ecologists are increasingly recognizing the important role that soil microbes play with regard to ecosystem function, and tools are readily available to measure microbial community composition (Drenovsky et al. 2008; Chodak et al. 2016).
The aim of our study was to assess the effects of predators in a terrestrial, temperate forest-floor web by examining multiple trophic levels, including the microbes, and to do so using an unfenced plot design. We explored how the removal of single and multiple predators from beneath artificial cover objects (ACOs) affected macro- and mesofauna, microbes (fungi and bacteria), and rates of leaf litter decomposition in a mixed deciduous forest in northeast Ohio, USA. We hypothesized that the removal of focal predators would result in indirect effects that would be detectable at multiple trophic levels radiating out from the focal point of predator removal (i.e., from ACOs to surrounding litter). We additionally predicted that Eastern Red-backed Salamanders would have the strongest indirect effects because of their considerable abundance at our field site.

\section{Materials and Methods \\ Predator Removal}

On 12 and 13 April 2004, we placed 288 ACOs on the forest-floor in the Cuyahoga Valley National Park (CVNP), Summit County, Ohio $\left(41.229402^{\circ} \mathrm{N}, 81.517333^{\circ} \mathrm{W}\right.$; datum WGS84). The field site is mixed deciduous forest that is dominated by Acer saccharum (Sugar Maples), Fagus grandifolia (American Beeches), Liriodendron tulipifera (Tulip Poplars), and Quercus rubra (Red Oaks) and lies on a north/northeast-facing slope (elevational range 260-271 $\mathrm{m})$. We used white ceramic floor tiles measuring $30 \times 30 \mathrm{~cm}$ as ACOs, and we removed litter before placing the ACO in direct contact with the soil substrate. Natural cover was rare at the site and we did not use any natural cover in our design. Artificial cover objects have been used successfully in previous studies to sample salamanders (Davis 1997; Houze and Chandler 2002). We focused our removal efforts beneath ACOs because they are known to serve as defendable territories for Eastern Red-backed Salamanders during dry periods between rains, when they become refugia for important salamander prey (reviewed in Jaeger and Forester 1993; Mathis et al. 1995; Jaeger et al. 2016). The microhabitat beneath ACOs is structurally simple, and simple habitats do not generally support a diverse assemblage of predators (Langellotto and Denno 2004). In forests that experience periodic drying, however, these small spaces serve as aggregation points for intraguild predators and their 
desiccation-intolerant prey. The ACOs were arranged in 32 plots; each was separated by approximately two meters and in total covered a $20 \times 40-\mathrm{m}$ area. Each of the 32 plots consisted of a cluster of nine ACOs arranged in three rows with 1-m spacing between tiles, all of which received the same treatment application ( $n=8$ plots per treatment). We chose this spacing pattern because Eastern Red-backed Salamanders have small territories (Jaeger et al. 2016) and, at our field site, less than $5 \%$ of resident salamanders moved between adjacent ACOs (Reiter et al. 2014). Thus, we assumed that few salamanders moved from one treatment plot to the next. Each plot was assigned to one of four treatments: (1) no removals/controls (NR); (2) salamander removal (SR); (3) centipede removal (CR); and (4) all predator removal $(\mathrm{PR})$. Predators removed from the PR treatment included salamanders, centipedes, spiders, carabid beetles, and predatory flat worms (Bipalium spp.). We minimized the risk of spatial pseudoreplication by randomizing within rows (one of each treatment in each of eight rows) with the constraint that two identical treatments were not adjacent in a row above or below.

Data collection began on 23 April 2004 and continued through 2007. The field site was visited every 2 wk, except for winter months, through the end of 2005 and weekly beginning in spring 2006 through the duration of the study (total of 98 visits to remove predators from beneath ACOs). Sampling artificial cover at weekly frequencies does not appear to negatively affect cover quality (Marsh and Goicochea 2003). During each visit we hand-turned ACOs, counted and identified all macrofauna, and removed predators from the appropriate treatments. Plots were visited in random order to remove any daily temporal bias in sampling.

\section{Leaf Litter Decomposition}

We examined the indirect effect of predator removals on the rate of leaf litter disappearance using leaf bags with known amounts of mixed canopy litter placed in each of the 32 plots in early spring. On 21 March 2006 we collected and oven-dried $\left(60^{\circ} \mathrm{C}\right)$, for $3 \mathrm{~d}$, mixed leaf litter from our field site. We used mixed litter, rather than one species of leaves, to ensure that organisms experienced a natural microhabitat. We constructed 160 leaf bags (five for each of 32 plots) from black tulle fabric (2-mm mesh). Each bag was made from a square foot of mesh, rolled around $10 \mathrm{~g}$ of oven-dried leaf litter, and secured on both ends with zip strips. On 6 April 2006 five bags were randomly positioned, and secured with a thin metal stake, in a single row above the center ACO in each plot. Bags were left in place for just over 6 mo before the first bag was pulled. One bag was removed at random from each plot on 19 October 2006 and on 8 April, 13 June, 6 September, and 5 November 2007. After invertebrates were extracted from leaf bags, the litter bag samples were placed in a drying oven at $60^{\circ} \mathrm{C}$, dried to constant weight, and reweighed to obtain the percent litter mass loss over time and to calculate rates of decay.

\section{Invertebrates from ACOs and Leaf Bags}

The effect of the various predator removal treatments on nonintraguild predator invertebrate (mesofauna and macrofauna) abundance was evaluated two ways. First, large invertebrate detritivores were identified and counted from beneath ACOs during predator removals, and second we examined smaller mesofauna inhabiting the leaf bags used in our litter decomposition study after they were removed from the field site on the five previously mentioned sampling dates. Recall that litter bags were situated just above the center ACO in each of our 32 plots. Therefore, we were sampling the smaller invertebrate taxa a short distance from the focal point of the predator removal. We used Berlese extraction into $70 \%$ ethanol to separate invertebrates from leaf bag samples. Extractors were run for $72 \mathrm{hr}$ under a $40 \mathrm{~W}$ incandescent lamp. Invertebrates were then counted and identified to order, or to family in some cases. We used blind protocols for litter bag invertebrate sampling and identification to minimize potential investigator bias. Data are presented as density per gram dry leaf mass after decomposition.

\section{Soil Microbes from Phospholipid Fatty Acid (PLFA) Analysis}

Phospholipids are major components of cell membranes, and their polar heads and ester-linked side chains (FA) vary in composition between eukaryotes and prokaryotes (fungi vs. bacteria) and also among prokaryotic groups (Gram+ vs. Gram-). These compounds rapidly degrade upon cell death, making them good indicators of living organisms in soils (Vestal and White 1989). The PLFA can supply information about specific fatty acids that act as biomarkers of certain functional groups. The sum of all PLFAs provides a proxy for total microbial biomass (minus Archael biomass), and the number of PLFAs detected provides a rough diversity estimate. The PLFAs in our study were sampled from soil rather than from leaf litter because fatty acids with chains $>18$ carbons are found in both plant material and microbes, making it difficult to determine their origin. Also, PLFA is an effective method because it provides a snapshot of the living microbial community (Drenovsky et al. 2004) and it is useful for detecting broad changes among treatments (Bossio and Scow 1998).

On 7 May, 11 July, and 15 October of 2006, three soil subsamples (10.0 cm depth) from around the center ACO were taken from each replicate of our four treatment groups. The three subsamples from each of the 32 plots were immediately combined, homogenized by stirring, placed in 50-mL centrifuge tubes, and placed on ice for transport to a freezer $\left(-20^{\circ} \mathrm{C}\right)$ at John Carroll University, University Heights, OH. Soil removal instruments were sterilized with isopropyl alcohol between each sample extraction. Frozen soil samples ( 32 plots $\times 3$ dates $=96$ samples) were shipped to the Soil Microbial Ecology Lab at the University of California, Davis for blind PLFA analysis; the PLFA analysis was not possible for one of the 96 soil samples.

\section{Statistical Analyses}

To test the null hypothesis that predator removal would not influence leaf litter decomposition, we used a general linear model (GLM) with treatment as a fixed factor and designated date as a random factor. Percent litter remaining was the response variable in our analysis. We additionally used an exponential decay model to estimate the rate of litter decay. The decomposition coefficient $(k)$ was estimated with the equation $y=e^{-k x}$, where $y$ is the original mass remaining, $e$ is the natural $\log$, and $x$ is the time given in weeks. The higher the $k$ value, the faster the decomposition 
TABLE 2.- The effectiveness of our ability to depress predator numbers via removal of individuals. Values (means $\pm 1 \mathrm{SE}$ ) are reported per sampling date and total percent reduction for each predator group in control plots (NR) compared to the appropriate removal plots. Significant results are indicated in bold. ${ }^{\mathrm{a}}$

\begin{tabular}{lccccc}
\hline Predator removed & $\begin{array}{c}\text { Mean no. } \\
\text { in NR }\end{array}$ & $\begin{array}{c}\text { Mean no. } \\
\text { in removal }\end{array}$ & $\begin{array}{c}\% \\
\text { Reduction }\end{array}$ & $F_{3,160}$ & $P$ \\
\hline Salamanders & $2.28 \pm 0.01$ & $1.64 \pm 0.01$ & 28 & 71.53 & $<\mathbf{0 . 0 0 0 1}$ \\
Spiders & $2.27 \pm 0.01$ & $1.86 \pm 0.01$ & 18 & 87.11 & $<\mathbf{0 . 0 0 0 1}$ \\
Carabid beetles & $1.09 \pm 0.01$ & $0.75 \pm 0.01$ & 31 & 24.43 & $\mathbf{0 . 0 1}$ \\
Centipedes & $0.71 \pm 0.01$ & $0.66 \pm 0.01$ & 7 & 2.46 & 0.99 \\
\hline
\end{tabular}

${ }^{a}$ Note: $F$ values are between-subjects effects from our ANOVA. Dunnett T3 was used as a post hoc test because of unequal variance among groups. NR $=$ control plots.

rate (Olson 1963). Analyses on leaf litter decomposition were constrained to our first four sampling dates because, by the end of the experiment, the litter bags were on average $\sim 2 \mathrm{~g}$ heavier, presumably attributable to incursion of soil into the leaf bags.

To examine the effect of predators on macroinvertebrates under ACOs, we compared numbers of invertebrates, represented by eight common taxa (treated as eight dependent variables) in control arrays (NR), to the predator removal treatments (SR, PR, or CR) using analysis of variance (ANOVA). Rare taxa that made up $<1 \%$ of the total number of individuals counted were excluded from the analysis. A separate analysis was then used to compare the mesofauna extracted from our leaf bags among treatments. Again, we limited our analysis to only those taxa that made up $>1 \%$ of the total. Response variables were the numbers of invertebrates of each taxon and the Shannon's diversity indices for the invertebrate community residing in each leaf bag. Two of the 160 invertebrate samples from leaf bags were lost to experimenter error (one from CR one from PR). All invertebrate data were $\log _{10}(x+1)$ transformed. Dunnett T3 was used as a post hoc test because of unequal variance among groups.

We evaluated the soil microbial community (as represented by PLFA biomarkers from soil samples) among treatments and the control. We used individual GLMs to consider the following response variables (total number of PLFAs, total bacterial PLFAs, total fungal PLFAs, and fungal:bacterial ratios, and to examine the effects of two fixed factors (treatment [CR, SR, PR, control (NR]) and sampling date (May, July, October) as well as the interaction between the two. Statistical comparisons were made among plots and, therefore, each treatment was replicated eight times. When results were significant at $P<0.05$, differences among means were assessed using univariate tests.

Principal components (PCs) of the PLFA data were used to decrease the dimensionality of the microbial data set and to minimize the likelihood of a type I error that might have occurred if each fatty acid was analyzed separately (Walton 2013). The PCs were also used to identify PLFAs that responded to treatment manipulations in similar ways, and PCs with eigenvalues $>1$ were retained for our analyses. Tests of individual PLFAs were limited only to those that loaded heavily on PCs that were significantly affected by our treatments. Only PLFAs that made up $>1 \%$ of the total for each sample were analyzed. Repeated measures tests would have been inappropriate in testing for treatment effects in our data set because the test assumes that conditions do not vary among sampling dates (McCall and Appelbaum 1973). Conditions at our field site varied day to day and seasonally, and these factors influence surface activity of all organisms of interest in our study. We used SPSS (v18.0, SPSS Inc., Chicago, IL) for all statistical analyses.

\section{RESULTS}

Removal treatments (CR, SR, and PR) had an effect on the predator community at our field site. For example, salamanders were more abundant in the centipede removal treatment (mean salamanders $=2.68 /$ plot) relative to the salamander removal treatment (mean salamanders $=1.64$ / plot) and to the control (mean salamanders $=2.28 /$ plot; data presented in Hickerson et al. 2012). We were able to decrease focal predators in all treatments except centipede removals (Table 2). Centipedes reinvaded the ACOs most rapidly and by the following collection date had reached $93 \%$ of their original numbers.

\section{Leaf Litter Decomposition}

After $20 \mathrm{mo}, 30 \%$ of the original mixed litter from leaf bags had disappeared. Litter decay rates were fastest in the multiple predator removal followed by single predator removal treatments $(\mathrm{SR}, \mathrm{CR})$ and the control, respectively (Fig. 1a; Table 3). Treatment had an effect on mass remaining in our litter bags (Fig. 1b; Table 3). Multiple comparisons revealed that litter remaining in the leaf bags was reduced in the multiple $\mathrm{PR}$ treatment relative to the treatments with elevated numbers of salamanders (PR vs. CR, $P=0.04$; PR vs. NR [control], $P=0.05)$.

\section{Invertebrates from ACOs and Leaf Bags}

We counted and identified over 62,000 invertebrates belonging to eight macrodetritivore categories from beneath ACOs over the 4-yr study. All eight categories are potential prey of both salamanders and centipedes, but they are not necessarily the preferred prey of these predators. Of those, isopods (Isopoda, 68\%) and millipedes (Diplopoda, 22\%) made up the majority by number ( $90 \%$ of the total). Under ACOs, four invertebrate groups (millipedes, slugs [Gastropoda], isopods, and numbers of ant colonies [Formicidae]) appeared to be positively associated with increased salamander abundance and negatively associated with increased centipede abundance (Fig. 2; Table 4). This relationship was most evident when we compared plots with the most salamanders $(\mathrm{CR}$; mean salamanders $=2.68 / \mathrm{plot})$ to those with the fewest (SR and PR; mean salamanders $=1.64 /$ plot). Here, differences were significant for millipedes (Fig. 2a), isopods (Fig. 2b), and slugs (Fig. 2c). All were most abundant in centipede removal plots and least abundant in SR plots (Fig. 2; Table 4). Although the effectiveness of centipede removal was not detectable by the next sampling date, the immediate and short-term response by guild members to each removal must have been sufficient to drive the differences that we observed. The number of ant colonies increased over the 4-yr study in controls and were also most numerous in centipede removal plots $(\mathrm{CR}$, mean $=$ $0.78 /$ plot) and least numerous in salamander removal plots $(\mathrm{SR}$, mean $=0.43 /$ plot; Fig. $2 \mathrm{~d})$.

We counted and identified over 29,000 individual mesofauna belonging to 25 categories from 160 leaf bags. 

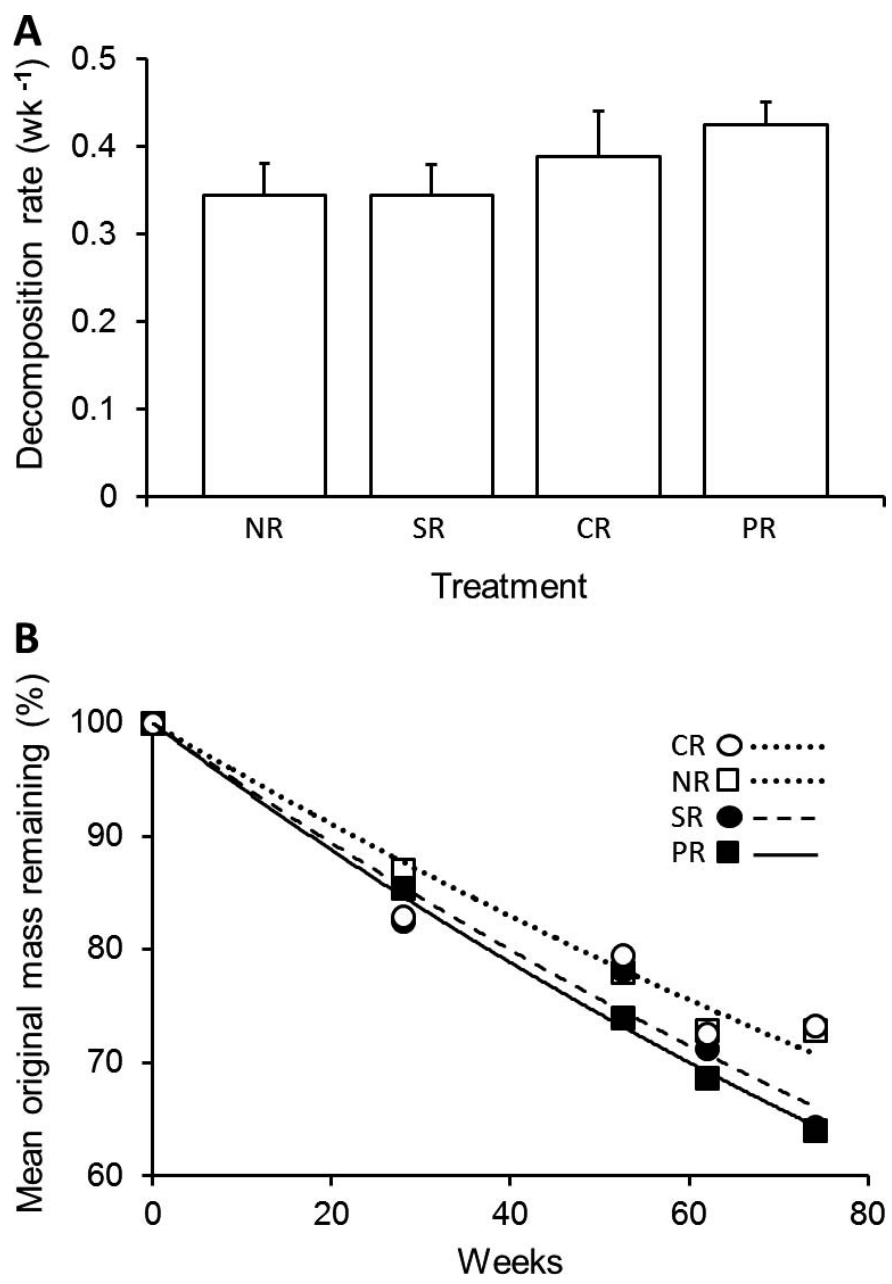

FIG. 1.- The effect of predator removal on mixed leaf litter decomposition. (A) Mean ( $+1 \mathrm{SE}$ ) rate of leaf litter decomposition measured as percent mass lost per week. (B) Mean mass remaining in the three treatments and the control over an 80 -wk period. Open squares $=$ controls, $\mathrm{NR}$; open circles $=$ centipede removals, $\mathrm{CR}$; closed circles $=$ salamander removals, SR; and closed squares = all predator removals, PR. The dotted line is presented for both CR and NR because the decay models were identical for these treatments.

Mites (Acari) and springtails (Collembola) made up 89\% of the total invertebrates by number. Springtails were slightly more abundant than mites ( $48 \%$ and $41 \%$ respectively). Of the 25 taxa identified, only the most abundant (the 10 taxa that made up $>1 \%$ of the total) were used in our statistical analysis. Total invertebrate abundance and diversity did not differ among treatments in our leaf bags. Overall we found no effect of predator removal $\left(F_{3,160}=1.12, P=0.19\right)$, but date had a strong effect on the invertebrate abundances in our leaf bags $\left(F_{2,160}=10.52, P<0.0001\right)$. Of the 10 individual taxa analyzed, only gamasid mites were affected by our treatment applications, and they were more abundant in centipede removal ( mean $=7.50 / \mathrm{g}$ dry litter) compared to the control treatments $\left(\right.$ mean $=4.89 / \mathrm{g}$ dry litter; $F_{3,160}=$ $2.77, P=0.04)$. There were no treatment effects on the various groups of abundant Collembola but there were differences among seasons. For example, isotomids, onychiurids, and neelids were most abundant in fall. Tomocerids were most abundant in summer and sminthurids in spring. We calculated species diversity of invertebrates from the leaf
TABLE 3.-Mean percent mixed deciduous leaf litter remaining from eight replicate litter bags per treatment on each of four sampling dates. Values represent percentages of original mass $(10 \mathrm{~g}) . \mathrm{PR}=$ all predator removal, $\mathrm{SR}=$ salamander removal, $\mathrm{CR}=$ centipede removal, and $\mathrm{NR}=$ control. $^{\mathrm{a}}$

\begin{tabular}{lccccc}
\hline Treatment & $\begin{array}{c}\text { October } \\
2007\end{array}$ & $\begin{array}{c}\text { April } \\
2008\end{array}$ & $\begin{array}{c}\text { June } \\
2008\end{array}$ & $\begin{array}{c}\text { September } \\
2008\end{array}$ & $\begin{array}{c}\text { Mean } \\
\text { (treatment) }\end{array}$ \\
\hline PR & 85.43 & 74.00 & 68.72 & 64.08 & 73.06 \\
SR & 84.84 & 78.21 & 75.25 & 69.09 & 76.85 \\
CR & 86.14 & 79.51 & 72.63 & 73.28 & 77.89 \\
NR (control) & 87.04 & 78.01 & 72.88 & 72.86 & 77.70 \\
Mean (date) & 85.86 & 77.43 & 72.37 & 69.83 &
\end{tabular}

${ }^{a}$ Note: There were treatment effects on litter decomposition $\left(F_{3,9}=5.20, P=0.02\right)$. Sampling date had an effect on litter decay $\left(F_{3,9}=51.00, P<0.0001\right)$. There was no interaction between treatment and date $\left(F_{3,9}=0.38, P=0.95\right)$.

bags and found no effect of treatment $\left(F_{3,160}=1.62, P=\right.$ $0.19)$ or date $\left(F_{3,160}=0.48, P=0.75\right)$.

\section{Soil Microbes from PLFA Analysis}

A total of 65 PLFAs were found in our soil samples. The number of PLFAs (a proxy for diversity) did not differ in treatments compared to controls (Tables 5 and 6; Vestal and White 1989; Bossio and Scow 1998; Potthoff et al. 2006). Mean microbial biomass and diversity (i.e., number of fungal and bacterial PLFAs) were highest in the control and lowest in the centipede removal plots (Table 6), although this trend was not statistically significant (Table 5). The fungal:bacterial ratio increased in the centipede removal treatment relative to the control (Tables 5 and 6) and differed between May $($ mean $=0.057 \pm 0.039)$ and July $($ mean $=0.070 \pm 0.038$; $\left.F_{3,27}=3.12, P=0.05\right)$.

Microbial community composition differed among treatments and the control. There were nine principal components (PCs) that had eigenvalues $>1$ and these made up $83 \%$ of the total variation in PLFAs detected from our soil samples. Factor scores from those nine principal components (PCs) were retained as dependent variables in our analyses. Independent fixed factors included treatment (NR, CR, PR, and SR) and date (May, July, and October). We found an overall effect of treatment $\left(F_{3,27}=2.22, P=0.001\right)$ and date $\left(F_{2,18}=10.32, P<0.0001\right)$ but failed to detect twoway interactions $\left(F_{6}=0.92, P=0.64\right)$. Fungi were largely unaffected, but bacteria (represented by PC1) were suppressed within centipede removal $(\mathrm{CR})$ plots where salamanders were most abundant (treatment, $F_{3}=3.15, P=$ 0.03; date, $F_{2}=2.46, P=0.09$, Fig. 3a). Two PLFA markers responded most strongly, $18: 1 \omega 7 \mathrm{t}$ (treatment, $F_{3}=7.02, P<$ 0.001 ; date, $F_{2}=1.34, P=0.27$; Fig. $3 \mathrm{~b}$ ) and $15: 03 \mathrm{OH}$ (treatment, $F_{3}=3.06, P<0.034$; date, $F_{2}=3.17, P=0.05$; Fig. 3c), declining by $13 \%$ within CR plots.

\section{DisCUSSION}

We examined the effect of predator removal from unfenced field plots in a temperate forest-floor food web to determine if the removal of single and multiple predators would cause a trophic cascade that would be detectable at lower trophic levels within the web. There were strong treatment effects on intraguild predators (see Hickerson et al. 2012), some groups of macrodetritivores quantified from beneath artificial cover objects (ACOs), and one group of microbivores (gamasid mites) from litter bags in our unfenced field plots. Salamanders in our plots also 

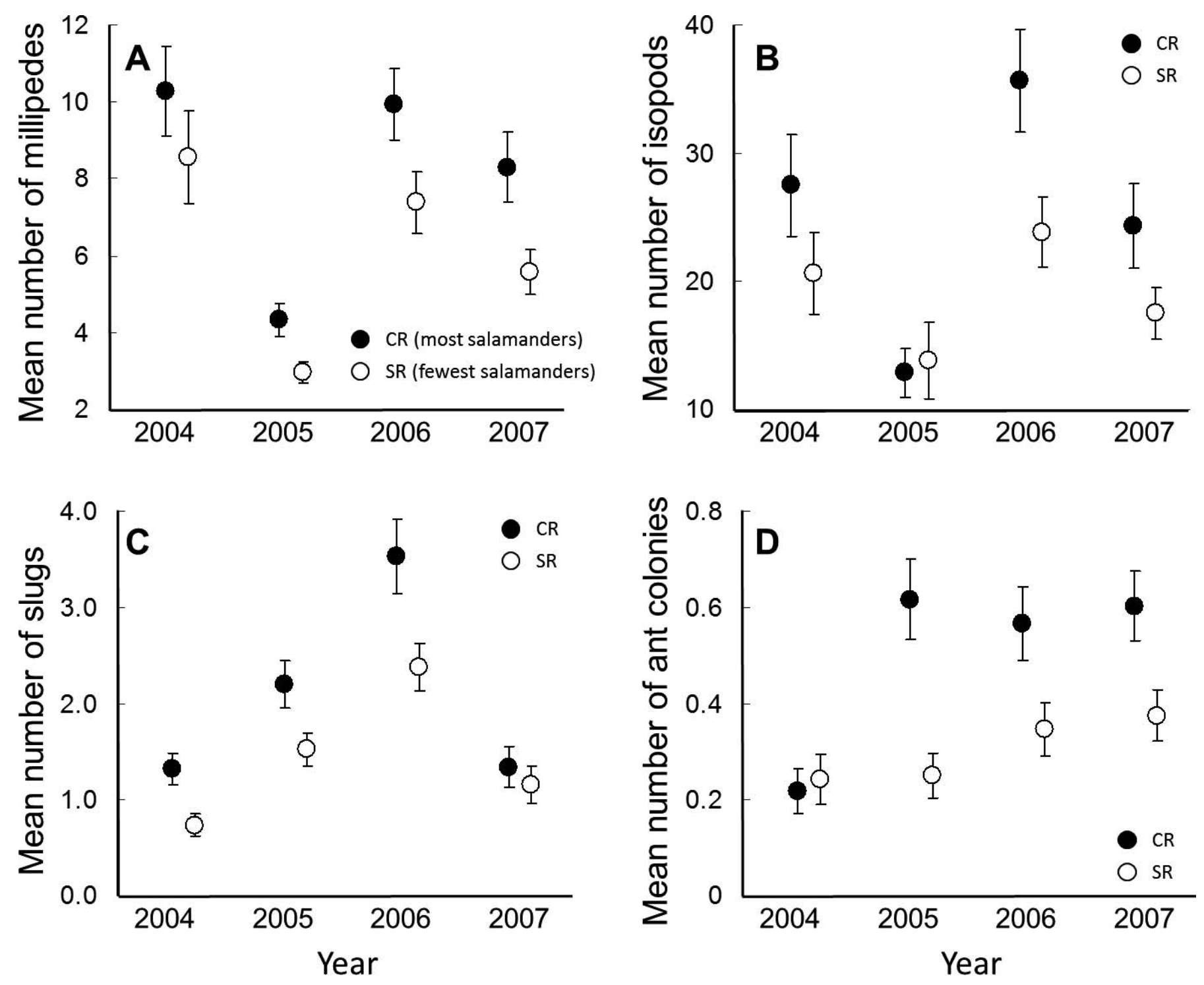

FIG. 2.-Numbers of (A) millipedes, (B) isopods, (C) slugs, and (D) ant colonies per replicate $(n=8)$ observed under artificial cover objects with the most salamanders (centipede removal [CR], filled circles) compared to those with the fewest salamanders (salamander removal [SR], open circles) over a 4-yr period. Values are depicted as means $\pm 1 \mathrm{SE}$.

suppressed bacteria estimated from PLFA analysis of the soil and slowed leaf litter decomposition.

\section{Predator Effects on Litter Decomposition}

This is the first study we are aware of that has observed effects of Eastern Red-backed Salamanders on mixed leaf litter decomposition in open field plots. Leaf litter in plots

TABLE 4.-Mean change in abundance of detritivores and ant colonies in plots with the most salamanders $(\mathrm{CR}=$ centipede removal) relative to plots with the fewest salamanders (SR = salamander removal). Significant results are indicated in bold. ${ }^{\mathrm{a}}$

\begin{tabular}{lcccc}
\hline & \multicolumn{4}{c}{ Invertebrate Guild } \\
\cline { 2 - 5 } & Millipedes & Isopods & Slugs & No. ant colonies \\
\hline Mean change & $2.60 \pm 0.02$ & $6.27 \pm 0.03$ & $0.71 \pm 0.01$ & $0.20 \pm 0.04$ \\
$F_{3}$ & 11.35 & 13.44 & 8.18 & 14.06 \\
$P$ & $\mathbf{0 . 0 3 3}$ & $\mathbf{0 . 0 1 4}$ & $\mathbf{0 . 0 1 4}$ & $<\mathbf{0 . 0 0 0 1}$ \\
\hline \multicolumn{2}{c}{${ }^{a}$ Note: $F$ values }
\end{tabular}
test because of unequal variance anjects effects in with more salamanders decomposed slowest relative to plots with fewer salamanders which decomposed the fastest. The trend of a faster decay rate in the multiple predator removal treatment might have been the result of a slight positive, indirect effect of predator removals on detritivores under cover objects in those plots, a microhabitat that was not assessed for mesofauna in our study. Previous studies

TABLE 5.-Statistical results for phospholipid fatty acid (PLFA) variables in soil samples from the control and predator removal treatments. Significant results are indicated in bold.

\begin{tabular}{|c|c|c|c|c|c|c|}
\hline \multirow[b]{2}{*}{ PLFA variables } & \multicolumn{2}{|c|}{ Treatment $(\mathrm{T})$} & \multicolumn{2}{|c|}{ Month (M) } & \multicolumn{2}{|c|}{$\mathrm{T} \times \mathrm{M}$ interaction } \\
\hline & $F_{3}$ & $P$ & $F_{2}$ & $P$ & $F_{6}$ & $P$ \\
\hline No. PLFAs (diversity) & 0.52 & 0.67 & 4.68 & 0.01 & 2.05 & 0.07 \\
\hline Total biomass & 1.60 & 0.20 & 1.45 & 0.24 & 0.55 & 0.77 \\
\hline Fungi & 0.36 & 0.78 & 0.28 & 0.76 & 1.49 & 0.19 \\
\hline Bacteria & 2.19 & 0.10 & 0.45 & 0.64 & 0.59 & 0.73 \\
\hline Fungi:bacteria & 3.04 & 0.03 & 3.12 & 0.05 & 1.18 & 0.42 \\
\hline
\end{tabular}


TABLE 6.- Mean phospholipid fatty acid (PLFA) concentration detected in soil samples from the control (NR) and predator removal treatments $(\mathrm{CR}$ $=$ centipede removal, $\mathrm{SR}=$ salamander removal and $\mathrm{PR}=$ all predator removal) during three sampling periods. The PLFA concentrations are given in $\mathrm{nmol} / \mathrm{g}$ soil

\begin{tabular}{llcrccc}
\hline Treatment & Month & $\begin{array}{c}\text { PLFA } \\
\text { concentration }\end{array}$ & $\begin{array}{r}\text { Total } \\
\text { biomass }\end{array}$ & Fungi $^{\mathrm{a}}$ & Bacteria $^{\mathrm{b}}$ & Fungibacteria $^{\mathrm{c}}$ \\
\hline NR & May & 52.25 & 107.99 & 14.36 & 28.60 & 0.044 \\
& July & 49.13 & 111.96 & 16.77 & 29.51 & 0.058 \\
& October & 49.13 & 100.42 & 15.85 & 28.88 & 0.058 \\
$\mathrm{CR}$ & Overall & 50.17 & 106.79 & 15.66 & 29.00 & 0.053 \\
& May & 50.25 & 93.76 & 14.39 & 22.94 & 0.06 \\
& July & 52.13 & 101.12 & 15.93 & 26.35 & 0.09 \\
& October & 47.63 & 83.85 & 13.37 & 22.58 & 0.061 \\
$\mathrm{SR}$ & Overall & 50.00 & 92.91 & 14.56 & 23.96 & 0.07 \\
& May & 53.14 & 109.21 & 17.47 & 28.17 & 0.057 \\
& July & 51.63 & 100.46 & 15.43 & 25.94 & 0.065 \\
& October & 48.25 & 91.80 & 13.67 & 24.57 & 0.056 \\
PR & Overall & 51.07 & 100.49 & 15.52 & 26.23 & 0.059 \\
& May & 51.63 & 97.49 & 14.01 & 25.04 & 0.065 \\
& July & 46.88 & 99.04 & 14.72 & 25.79 & 0.066 \\
& October & 50.38 & 102.17 & 17.38 & 28.29 & 0.068 \\
& Overall & 49.63 & 99.57 & 15.37 & 26.37 & 0.066 \\
\hline
\end{tabular}

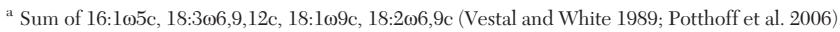

${ }^{\mathrm{b}}$ Sum of 15:0i, 15:0a, 15:0, 16:0i, 16:0a, 17:0, 17:0i, 17:0a, 17:0c, 19:0c (Potthoff et al. 2006).

${ }^{c}$ 18:206c/15:0i, 15:0a, 15:0, 16:0i, 16:0a, 17:0, 17:0i, 17:0a, 17:0c, 19:0c (Bossio and Scow 1998).

examining the effects of salamander predators on litter decay have found conflicting results (Table 1). For example, plethodontid salamanders have been reported to decrease rates of decay (Wyman 1998; Best and Welsh 2014; this study) and in other cases have had no effect on litter decay (Walton and Steckler 2005; Homyack et al. 2010; Hocking and Babbitt 2014). Similar conflicting results have been reported for the effect of spiders on litter decay. One study reported increased rates of litter decay (Lawrence and Wise 2004) and another reported decreased rates of litter decomposition (Lawrence and Wise 2000) in the presence of spiders. A recent study in a lowland tropical forest in Costa Rica reported increased litter decomposition in mesocosms with ants compared to those without (McGlynn and Poirson 2012). The authors found that, in litter bags with mesh sizes that allowed for the entry of smaller arthropods (e.g., Collembola) but excluded larger predators like ants, decomposition was best explained by the local biomass of the ants in the vicinity of the bags. They further suggested that the small prey of ants use the litter bags as refugia from predation. In our study, decomposition was accelerated in the plots with fewer predators, salamanders included (PR, SR). Perhaps leaf-fragmenting arthropods were released from predation and able to contribute to increases in litter loss.

Predator Effects on Invertebrates from ACOs and Leaf Bags

We found that predators affected the distribution and abundance of some macrodetritivores at our field site. It has been reported that salamander predation can decrease numbers of large detritivores (Wyman 1998; Walton and Steckler 2005; Walton et al. 2006). Our results differ from these studies because we found more millipedes, slugs, and isopods in plots with the most salamanders (CR). In the previously described studies, which were conducted in laboratory mesocosms (Walton and Steckler 2005; Walton et al. 2006) and in field enclosures (Wyman 1998), predators
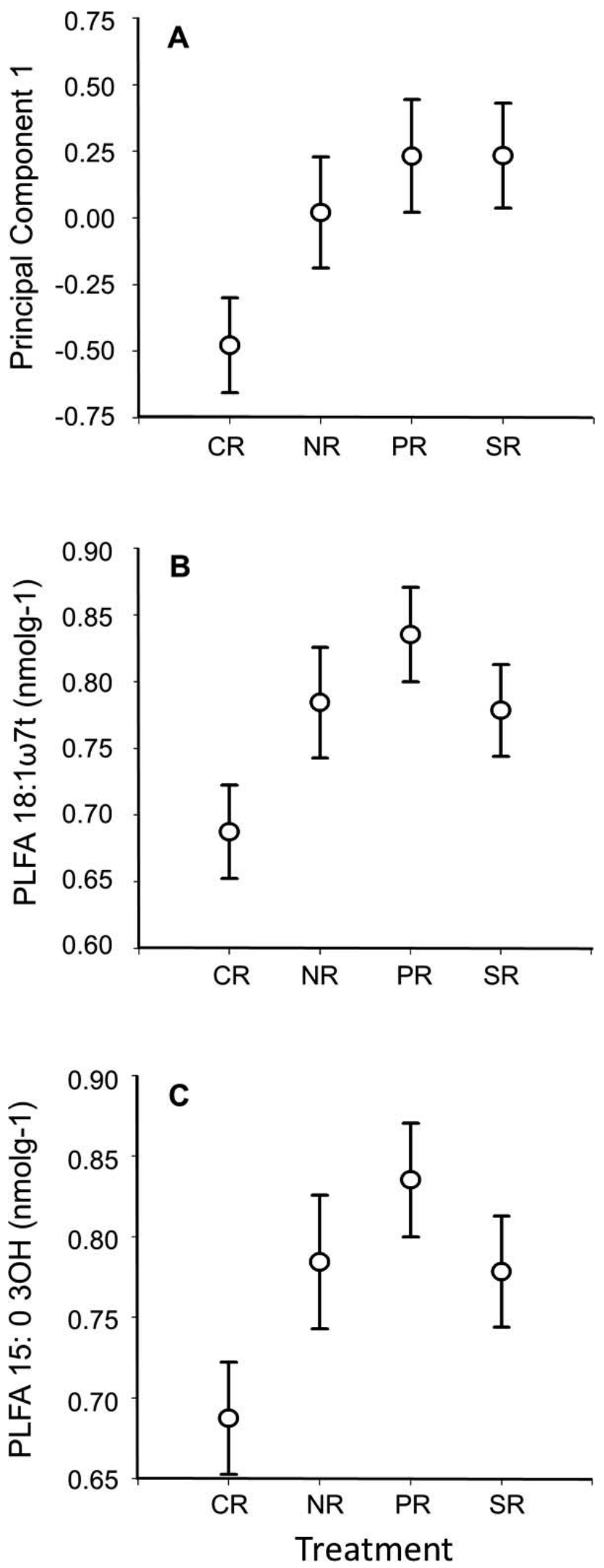

FIG. 3.-Response metrics for phospholipid fatty acid (PLFA) analyses as a function of predator removal treatment. (A) Principal component (PC) 1 was lower in $\mathrm{CR}$ plots compared to controls $\left(F_{3}=3.15, P=0.03\right)$. Individual PLFAs. (B) 18:1 $\omega 7$ t and (C) 15:0 3OH explained PC1 and were lower in the CR treatment $\left(F_{3}=7.02, P=0.001\right.$ and $F_{3}=3.06, P=0.03$ respectively). $\mathrm{CR}=$ centipede removal, $\mathrm{NR}=$ control (nothing removed), $\mathrm{PR}=$ all predator removal, and $\mathrm{SR}=$ salamander removal. Values are indicated as means $\pm 1 \mathrm{SE}$. 
(salamanders) were enclosed with their prey. With few alternatives and little refuge for the prey, predators were able to have negative effects, even on taxa that are not typically important diet items (e.g., millipedes, slugs). In our unrestricted field design, predators were free to forage optimally on preferred prey items, which could have recolonized plots as they became depleted. Resident salamanders that exclude guild members via behavioral interactions such as aggression (Gall et al. 2003; Hickerson et al. 2004, 2012) might generate a net benefit for other arthropods that are not typically the preferred prey of territorial resident Eastern Red-backed Salamanders. The diet of Eastern Red-backed Salamanders is well characterized (Maglia 1996; Adams and Rohlf 2000; Maerz et al. 2006) and the preferred prey of this species consists largely of mites, Collembola, and other small, less-chitinous prey such as fly larvae (Jaeger 1990; Jaeger et al. 1995). We observed increased numbers of macrodetritivores in centipede removal plots relative to the control. It is also possible that centipedes prey upon large detritivores, so although we were unable to detect an overall reduction in centipedes in our CR plots, we did effectively reduce centipede numbers under ACOs each sampling day. This temporary reduction in centipedes might have allowed for the invasion of macrodetritivores from the surrounding habitat as they were released from predation by centipedes. The diet of centipedes is largely unknown; however, it seems reasonable that venomous predators would be able to subdue larger prey items.

We found no effect of predator removals on mesofauna taxa quantified from leaf bags next to our ACOs with the exception of one taxon, gamasid mites. These predatory mites were more abundant in centipede removal plots $(\mathrm{CR})$ compared to controls (NR). Top-down effects on mesofauna abundance might have been weak on most taxa in our litter bags for the following reasons: (1) large predators might have been unable to enter the bags; (2) the microhabitat in the litter bags might have been sufficiently complex relative to the area beneath the ACOs to allow for fewer encounters among litter occupants; (3) web structure (i.e., microhabitat complexity, omnivory, species diversity etc.) might have effectively attenuated or weakened the effect of predator manipulation on litter bag invertebrates; and (4) replacement of one predator by a different, but functionally equivalent, predator might have resulted in reduced suppression of mesofauna in our leaf bags.

Given that the mesh size of our leaf bags was $2 \mathrm{~mm}$, it would have been unlikely that most adult macrofauna could enter the bags. In some cases, it might have been possible for larval forms to enter the leaf bags and become trapped if they metamorphosed while in the bag, but large predators (e.g., salamanders and spiders) were unable to enter the bags. A meta-analysis of literature published from the 1960s to the end of 2005 on litter bag studies investigating the role of microarthropods on decomposition suggested that the effects on decomposition reported are cumulative effects of the true microarthropod effect plus mesh size effects (Kampichler and Bruckner 2009). When the data were corrected for the estimated mesh size effect, the results revealed negative effects of microarthropods on decomposition, a result opposite to the widely accepted idea that microarthropods have a positive effect on litter decay. The authors concluded that after 40 years of litter bag studies our knowledge is still limited on the matter. Because our experiment was not designed to include a comparison of the effect of different mesh sizes, we do not know whether our treatment applications in the surrounding field array affected interactions within the litter bags. It is probable that the microhabitat within the litter bags differed substantially from the simple habitat beneath the ACOs.

We removed predators from beneath ACOs defended as territories by Eastern Red-backed Salamanders. It was within this specifically defined microhabitat that we expected interactions among the macrofauna to affect lower trophic positions, at least during periods between rain events when prey resources are limited to areas where moisture is retained beneath cover objects. It is possible, however, that the strong effects found under ACOs were attenuated in the surrounding area because of microhabitat complexity that exists in forest litter but is reduced beneath cover objects on the forest-floor. Trophic cascades are expected to be weak, both in complex habitats and in complex webs, relative to more-simple ones (Polis and Strong 1996; Pace et al. 1999). For example, omnivory resulting in increased connectivity within diverse food-webs might dissipate trophic cascades because of the increased number of potential pathways in the web (Polis and Strong 1996). Functional redundancy refers to species that have the same functional role in communities or ecosystems, such that loss of richness does not affect overall system function (Lawton and Brown 1993) and is one factor that can increase web connectivity. Recent utilization of classic Lotka-Volterra competition models to address the likelihood of the occurrence of functional redundancy in nature suggests that it is incompatible with coexistence. Spatial and temporal variation might allow for functional redundancy at the microhabitat scale (e.g., in leaf litter), however, and within a functional group (e.g., predators; Loreau 2004). The presence of top predators in forest-floor webs with broad and extensively overlapping diets might explain why we found little overall effect of the removal of one or only a few predators from beneath ACOs on mesofauna from our litter bags. For example, in plots in which salamanders were removed (SR), there were increases in spider abundance (Hickerson et al. 2012). If spiders and salamanders share prey, and consume similar amounts, there might be little effect of the treatment application on invertebrate abundances. Studies that assess diet overlap and functional equivalence of various predators would be necessary to tease apart these potential connections.

\section{Predator Effects on Microbes}

Although we found little effect of predator removal on mesofauna abundance in leaf litter bags from our field plots, we did find an effect of predator removal on leaf litter decomposition and on the microbial community as estimated from phospholipid fatty acid (PLFA) analysis of soil taken from the places within our plots where our litter bags resided. Diversity and biomass of the microbes in our soil samples, as measured by summing total, fungal, and bacterial PLFAs were not affected, but we did observe strong effects on principal components from our data reduction analysis. We found little effect of predator removal on the fungal community, but bacteria were suppressed in plots where salamanders, millipedes, isopods, slugs, ant colonies, and 
gamasid mites were most abundant (CR), a result consistent with other studies and with the idea that top-down control of fungi is limited as a result of excess growth in response to grazing (Wardle 2002). A review of 42 mesocosm studies that measured effects of soil fauna on microbial biomass found that bacterial grazers (e.g., predatory mites) had a stronger influence on microbial biomass than did fungivores (e.g., Collembola; Sackett et al. 2010). Microbial biomass was lowest in the CR treatment, and this result was primarily driven by the suppression of bacterial PLFA markers. It is possible that the increase in gamasid mites in the CR treatment had a direct, negative effect on the soil bacteria in that treatment, an explanation consistent with similar studies (Loreau 2004).

At our field site, salamanders were most abundant in the centipede removal (CR) treatment $(n=2,105)$, followed by the control NR $(n=1,784)$, and then the salamander removal (SR) and multiple predator removal (PR) treatments ( $n=1,288$ and 1,287, respectively). Although the reduced biomass of some bacteria and a decrease in litter decomposition in CR plots was consistent with the hypothesis of a salamander-initiated trophic cascade, additional results vitiate that explanation. Firstly, neither bacterial nor fungal biomass was enhanced within the salamander removal (SR) treatment, despite a 28\% decrease of Eastern Red-backed Salamander density in SR plots. Secondly, we did not observe increased densities of Collembola, as hypothesized based on results from previous studies (Rooney et al. 2000; Walton and Steckler 2005; Walton et al. 2006). Rather, arthropod predators of Collembola, (e.g., gamasid mites and carabid beetles) and potential competitors of Collembola for detrital resources (e.g., isopods, millipedes, and slugs) were all more abundant on CR plots, perhaps contributing to bacterial suppression and litter retention in these plots.

Full resolution of the mechanism(s) was beyond the scope of this study. Another plausible mechanism potentially responsible for the suppression of bacteria in CR plots, however, could be the presence of strong interactions between soil bacteria and the cutaneous bacteria that reside on the epidermis of Eastern Red-backed Salamanders. The bacterial community that resides on the skin of terrestrial, direct-developing frogs and salamanders that brood their eggs has the ability to inhibit the growth of fungal pathogens that attack embryos (Austin 2000). These cutaneous bacteria are host species-specific and differ from the microbial community found in the soil (Austin 2000; Culp et al. 2007). Adult Eastern Red-backed Salamanders at our study site exhibit site fidelity and homing behavior (Reiter et al. 2014). Such long-term residence would provide ample opportunity for salamanders to disperse their characteristic microflora through skin secretions and feces. Perhaps the additional density of Eastern Red-backed Salamanders within the CR plots was sufficient to tip the balance of antibiotic competition among microbes in favor of certain salamander-associated microflora at the expense of some soil bacteria. This possibility could be explored further by designing experiments that would compare soil microbial assemblages in salamander territories to the soil microbial communities in microhabitats not occupied by salamanders.

Regardless of the mechanisms responsible for the indirect effects presented here, this is the only study that we are aware of that has detected changes in the abundance of organisms at the microbial level, and at the level of the basal resource (leaf litter), from predator-manipulated open/ unfenced field plots in an eastern North-American deciduous forest-floor food web. Our results contribute importantly to a growing body of evidence indicating that territorial predators, such as Eastern Red-backed Salamanders, which are often constrained to spatially fixed microhabitats, can be strong regulators of guild members (Hickerson et al. 2012) and lower trophic levels, at least at small spatial scales. Our results also indicate the importance of top-down, predatormediated regulation of species composition and litter decomposition in a temperate forest-floor, detrital food web (reviewed in Bruce 2008), a system that is commonly thought to be regulated primarily through bottom-up effects.

Acknowledgments.-The Cuyahoga Valley National Park granted permission to conduct fieldwork (Permit number CUVA-2004-SCI-0010) and the Institutional Animal Care and Use Committees of John Carroll University (Protocol no. JCU503) and Cleveland State University (Protocol no. 2604-WAL-AS) granted permission to work with live animals. CMH was supported by a National Science Foundation Doctoral Dissertation Improvement Grant (DEB-0608239) and CDA was supported by a George Grauel Faculty Fellowship during portions of this study. We thank R. Drenovsky for helping with the collection of soil samples for our microbial analysis. G. Meszaros counted and identified invertebrates from leaf litter bags. C. Borden, K. Ivanov, O. Lockhart, N. Mikash, and J. Milligan helped place litter bags in the field. R. Drenovsky, J. Keiper, J. Johansen, and R. Midura provided helpful comments on an earlier version of this manuscript.

\section{Literature Cited}

Adams, D.C., and J.F. Rohlf. 2000. Ecological character displacement in Plethodon: Biomechanical differences found from a geometric morphometric study. Proceedings of the National Academy of Sciences 97:41064111.

Austin, R.M. 2000. Cutaneous microbial flora and antibiosis in Plethodon ventralis. Pp. 127-136 in The Biology of Plethodontid Salamanders (R.C. Bruce, R.G. Jaeger, and L.D. Houck, eds.). Kluwer Academic/Plenum Publishers, USA.

Beard, K.H., K.A. Vogt, and A. Kulmatiski. 2002. Top-down effects of a terrestrial frog on forest nutrient dynamics. Oecologia 133:583-593.

Beard, K.H., A.K. Eschtruth, K.A. Vogt, D.J. Vogt, and F.N. Scatens. 2003. The effects of the frog Eleutherodactylus coqui on invertebrates and ecosystem processes at two scales in the Luquillo Experimental Forest, Puerto Rico. Journal of Tropical Ecology 19:607-617.

Best, M.L., and H.H. Welsh, Jr. 2014. The trophic role of a forest salamander: Impacts on invertebrates, leaf litter retention, and the humification process. Ecosphere 5:1-19.

Bossio, D.A., and K.M. Scow. 1998. Impacts of carbon and flooding on soil microbial communities: Phospholipids fatty acid profiles and substrate utilization patterns. Microbial Ecology 35:265-278.

Bruce, R.C. 2008. Intraguild interactions and population regulation in plethodontid salamanders. Herpetological Monographs 22:31-53.

Burton, T.M., and G.E. Likens. 1975. Energy flow and nutrient cycling in salamander populations in Hubbard Brook experimental forest, New Hampshire. Ecology 56:1068-1080.

Chodak, M., B. Klimek, and M. Niklińska. 2016. Composition and activity of soil microbial communities in different types of temperate forests. Biology and Fertility of Soils 52:1093-1104.

Culp, C.L., J.O. Falkinham, III, and L.K. Belden. 2007. Identification of the natural bacterial microflora on the skin of eastern newts, bullfrog tadpoles, and redback salamanders. Herpetologica 63:66-71.

Davis, T.M. 1997. Nondisruptive monitoring of terrestrial salamanders with artificial cover objects on southern Vancouver Island, British Columbia. Herpetological Conservation 1:161-174.

Drenovsky, R.E., G.N. Elliott, K.J. Graham, and K.M. Scow. 2004. Comparison of phospholipids fatty acid (PLFA) and total soil fatty acid methyl esters (TSFAME) for characterizing soil microbial communities. Soil Biology and Biochemistry 36:1793-1800.

Drenovsky, R.E., K.P. Feris, K.M. Batten, and H. Krassimira. 2008. New and current microbiological tools for ecosystem ecologists: Towards a 
goal of linking structure and function. American Midland Naturalist 160:140-159.

Dunham, A.E. 2008. Above and below ground impacts of terrestrial mammals and birds in a tropical forest. Oikos 117:571-579.

Gall, S.B., C.D. Anthony, and J.A. Wicknick. 2003. Behavioral interactions between salamanders and beetles indicate a guild relationship. American Midland Naturalist 149:363-374.

Halaj, J., and D.H. Wise. 2001. Trophic cascades: How much do they trickle? American Naturalist 157:262-281.

Hickerson, C.M., C.D. Anthony, and J.A. Wicknick. 2004. Behavioral interactions between salamanders and centipedes: Competition in divergent taxa. Behavioral Ecology 15:679-686.

Hickerson, C.M., C.D. Anthony, and B.M. Walton. 2012. Interactions among forest floor guild members in structurally simple microhabitats. American Midland Naturalist 168:30-42.

Hocking, D.J., and K.J. Babbitt. 2014. Effects of red-backed salamanders on ecosystem functions. PloS One 9:e86854. DOI: 10.1371/journal.pone. 0086854

Homyack, J.A., E.B. Sucre, C.A. Haas, and T.R. Fox. 2010. Does Plethodon cinereus affect leaf litter decomposition and invertebrate abundances in mixed oak forest? Journal of Herpetology 44:447-456.

Houze, M.C., Jr., and R.C. Chandler. 2002. Evaluation of coverboards for sampling terrestrial salamanders in South Georgia. Journal of Herpetology 36:75-81.

Jaeger, R.G. 1990. Territorial salamanders evaluate size and chitinous content of arthropod prey. Pp. 111-126 in Behavioral Mechanisms of Food Selection (R.N. Hughes, ed.). NATO ASI Series, Subseries G Ecological Sciences. Springer-Verlag, Germany.

Jaeger, R.G., and D.C. Forester. 1993. Social behavior of plethodontid salamanders. Herpetologica 49:163-175.

Jaeger, R.G., J. Schwarz, and S.E. Wise. 1995. Territorial male salamanders have foraging tactics attractive to gravid females. Animal Behaviour 49:633-639.

Jaeger, R.G., B. Gollman, C.D. Anthony, C.R. Gabor, and N. Kohn. 2016. Behavioral Ecology of the Eastern Red-backed Salamander: 50 Years of Research. Oxford University Press, USA.

Johnson, D., M. Krsek, E.M.H. Wellington, A.W. Stott, L. Cole, R.D Bardgett, D.J. Read, and J.R. Leake. 2005. Soil invertebrates disrupt carbon flow through fungal networks. Science 309:1047.

Jung, R.E., S. Droege, J.R. Sauer, and R.B. Landy. 2000. Evaluation of terrestrial and streamside salamander monitoring techniques as Shenandoah National Park. Environmental Monitoring and Assessment 63:6579 .

Kampichler, C., and A. Bruckner. 2009. The role of microarthropods in terrestrial decomposition: A meta-analysis of 40 years of litterbag studies. Biological Reviews 84:375-389.

Langellotto, G.A., and R.F. Denno. 2004. Responses of invertebrate natural enemies to complex-structured habitats: A meta-analytical synthesis. Oecologia 139:1-10.

Lawrence, K.L., and D.H. Wise. 2000. Spider predation on forest-floor Collembola and evidence for indirect effects on decomposition. Pedobiologia 44:33-39.

Lawrence, K.L., and D.H. Wise. 2004. Unexpected indirect effect of spiders on the rate of litter disappearance in the deciduous forest. Pedobiologia 48:149-157.

Lawton, J.H., and V.K. Brown. 1993. Redundancy in ecosystems. Pp. 255270 in Biodiversity and Ecosystem Function (E.D. Schulze and H.A Mooney, eds.). Springer, Germany.

Loreau, M. 2004. Does functional redundancy exist? Oikos 104:606-611.

Maerz, J.C., E.M. Myers, and D.C. Adams. 2006. Trophic polymorphism in a terrestrial salamander. Evolutionary Ecology Research 8:23-35.

Maglia, A.M. 1996. Ontogeny and feeding ecology of the red-backed salamander, Plethodon cinereus. Copeia 1996:576-586.

Marsh, D.M., and M.A. Goicochea. 2003. Monitoring terrestrial salamanders: Biases caused by intense sampling and choice of cover objects. Journal of Herpetology 37:460-466.

Mathis, A., R.G. Jaeger, W.H. Keen, P.K. Ducey, S.C. Walls, and B.W Buchanan. 1995. Aggression and territoriality by salamanders and a comparison with the territorial behaviour of frogs. Pp. 633-676 in Amphibian Biology, vol. 2: Social Behaviour (H. Heatwole and B. Sullivan, eds.). Surrey Beatty \& Sons, Australia.

McCall, R.B., and M.I. Appelbaum. 1973. Bias in the analysis of repeatedmeasures designs: Some alternative approaches. Child Development 44:401-415.
McGlynn, T.P., and E.K. Poirson. 2012. Ants accelerate litter decomposition in a Costa Rican lowland tropical rain forest. Journal of Tropical Ecology $28: 437-443$

Mikola, J., and H. Setälä. 1998. No evidence of trophic cascades in an experimental microbial-based soil food-web. Ecology 79:153-164.

Milanovich, J.R., and W.E. Peterman. 2016. Revisiting Burton and Likens (1975): Nutrient standing stock and biomass of a terrestrial salamander in the midwestern United States. Copeia 104:165-171.

Olson, J.S. 1963. Energy storage and the balance of producers and decomposers in ecological systems. Ecology 44:322-331.

O'Neill, R.V., and D.A. Reichle. 1980. Dimensions of ecosystem theory. Pp. 11-26 in Forests: Fresh Perspectives from Ecosystem Analysis (R.H. Waring, ed.). Oregon State University Press, USA.

Pace, M.L., J.J. Cole, S.R. Carpenter, and J.F. Kitchell. 1999. Trophic cascades revealed in diverse ecosystems. Trends in Ecology and Evolution 14:483-488.

Polis, G.A, and D.R. Strong. 1996. Food-web complexity and community dynamics. American Naturalist 147:813-846.

Potthoff, M., K.L Steenwerth, L.E. Jackson, R.E. Drenovsky, K.M. Scow, and R.G. Joergensen. 2006. Soil microbial community composition as affected by restoration practices in California grassland. Soil Biology and Biochemistry 38:1851-1860.

Reiter, M.K., C.D. Anthony, and C.M. Hickerson. 2014. Territorial behavior and ecological divergence in a polymorphic salamander. Copeia 2014:3481-3488.

Ripple, W.J., J.A. Estes, O.J. Schmitz, V. Constant, M.J. Kaylor, A. Lenz, J.L. Motley, K.E. Self, D.S. Taylor, and C. Wolf. 2016. What is a trophic cascade? Trends in Ecology and Evolution 31:842-849.

Rooney, T.P., C. Antolik, and M.D. Moran. 2000. The impact of salamander predation on Collembola abundance. Proceedings of the Entomological Society of Washington 102:308-312.

Sackett, T.E., A.T. Classen, and N.J. Sanders. 2010. Linking soil food-web structure to above- and belowground ecosystem processes: A metaanalysis. Oikos 119:1984-1992.

Scheu, S., and H. Setälä. 2002. Multitrophic level interactions in decomposer food-webs. Pp. 223-264 in Multitrophic Level Interactions (T. Tscharnke and B.A. Hawkins, eds.). Cambridge University Press, UK.

Schmitz, O.J., P.A. Hamback, and A.P. Beckerman. 2000. Trophic cascades in terrestrial systems: A review of the effects of carnivore removals on plants. American Naturalist 155:141-153.

Semlitsch, R.D., K.M. O'Donnell, and F.R. Thompson, III. 2014. Abundance, biomass production, nutrient content, and the possible role of terrestrial salamanders in Missouri Ozark forest ecosystems. Canadian Journal of Zoology 92:997-1004.

Swift, M.F., O.W. Heal, and J.M. Anderson. 1979. Decomposition in Terrestrial Ecosystems. University of California Press, USA.

Vestal, J.R., and D.C. White. 1989. Lipid analysis in microbial ecology: Quantitative approaches to the study of microbial communities. Bioscience 39:535-541.

Walton, B.M. 2005. Salamanders in forest-floor food-webs: Environmental heterogeneity affects the strength of top-down effects. Pedobiologia 49:381-393.

Walton, B.M. 2013. Top-down regulation of invertebrates by a terrestrial salamander. Herpetologica 69:127-146.

Walton, B.M., and S. Steckler. 2005. Contrasting effects of salamanders on forest-floor macro and mesofauna in laboratory microcosms. Pedobiologia 49:51-60.

Walton, B.M., D. Tsatiris, and M. Rivera-Sostre. 2006. Salamanders in forest-floor food-webs: Invertebrate species composition influences topdown effects. Pedobiologia 50:313-321.

Wardle, D.A. 2002. Communities and Ecosystems: Linking the Aboveground and Belowground Components. Princeton University Press, USA.

Wardle, D.A., F. Hyodo, R.D. Bardgett, G.W., Yeates and M. Nilsson. 2011. Long-term aboveground and belowground consequences of red wood ant exclusion in boreal forest. Ecology 92:645-656.

Wyman, R.L. 1998. Experimental assessment of salamanders as predators of detrital food-webs: Effects on invertebrates, decomposition and the carbon cycle. Biodiversity and Conservation 7:641-650. 